\title{
ASSESSING THE PERFORMANCE OF IFAS SYSTEMS TO RAISE THE CAPACITY OF EXISTING WWTP*
}

\author{
Ola D.S. EL- monayeri ${ }^{1+}$, Abul-abbas E. Galal ${ }^{2}$ \\ ${ }^{1}$ Faculty of Environmental Eng., Arab Academy of Science \& Technology \& Maritime Transportation, Cairo. \\ ${ }^{2}$ Faculty of Engineering, Al_azhar University, Cairo.
}

\begin{abstract}
This paper focuses on using the Integrated Fixed-film Activated Sludge (IFAS) technology to retrofit wastewater treatment plants (WWTPs) specially those who are apt to receiving high fluctuations in organic loads. A model was constructed at the WWTP in the city of Zenien, Giza, Egypt, to study three flowrates: $1.013 \mathrm{~m}^{3} / \mathrm{d}, 3.04 \mathrm{~m}^{3} / \mathrm{d}$, and $6.08 \mathrm{~m}^{3} / \mathrm{d}$ with hydraulic retention times (HRTs): 18, 6, and 3 hours, respectively to be implemented for extended aeration system (EAS) IFAS technology.Field-obtained results were validated using computer modeling; GPS_X which is a vital tool in the evaluation of operating treatment plants. Results show that the EAS performs well with a HRT of 18 hours where the removal efficiency ranges from 85 to $92 \%$ for $\mathrm{BOD}_{5}$, COD, and TSS, which complies with literature except for TKN which is about $77 \%$. However the system fails to target the acceptable removal efficiency when the HRT decreases to 6 and 3 hours, the efficiency being in the range of 57 to $72 \%$ for the $6 \mathrm{hr}$ HRT and in the range of 34 to $66 \%$ for the 3 hour HRT. This indicates that the extended aeration process cannot resist high variations in organic loads or incoming flowrate. For the IFAS system used in this study, much better removal efficiencies are achieved. For HRT $18 \mathrm{hr}$, the removal ratio is $92 \%$ for BOD, COD and TSS and $80 \%$ for TKN, which is a higher level of performance compared to the extended aeration process. Furthermore, for the 6 hour HRT, the ratio ranges from 90 to $92 \%$ for BOD, COD, and TSS and $80 \%$ as well for TKN and, similarly, for the 3 hour HRT except that the removal of TKN decreases to about $75 \%$. Despite these promising results, further efforts would be recommended to identify reliable and profound design criteria for the IFAS technology as is the case with existing conventional and extended activated sludge systems.
\end{abstract}

KEY WORDS: Activated Sludge (AS) - Computer Modeling - Domestic Wastewater - Extended Aeration -F/M Ratio - GPS$\mathrm{X}$ - HRT - IFAS - Upgrading.

\section{ÉVALUATION DE LA PERFORMANCE DES SYSTÈMES IFAS À ACCROITRE LA CAPACITE DES STATIONS D'EPURATION EXISTANTS}

\section{RÉSUMÉ}

Ce document met l'accent sur l'utilisation du film fixe boues intégré Activé ( IFAS ) de la technologie pour les usines de traitement des eaux usées (STEP) équiper spécialement ceux qui sont aptes à recevoir de fortes fluctuations dans les charges organiques. Un modèle a été construit à la station d'épuration de la ville de Zenien, Gizeh, en Égypte, pour étudier trois débits : $1.013 \mathrm{~m} 3 / \mathrm{j}, 3,04 \mathrm{~m} 3 / \mathrm{j}$, et $6,08 \mathrm{~m} 3 / \mathrm{j}$ avec des temps de rétention hydrauliques ( HRT ) : 18, 6, et 3 heures, respectivement à mettre en œuvre pour le système d'aération prolongée ( EAS ) résultats IFAS technology.Field obtenus ont été validés en utilisant la modélisation informatique; GPS_X qui est un outil essentiel dans l'évaluation des stations d'épuration d'exploitation. Les résultats montrent que l' EAS fonctionne bien avec une HRT de 18 heures où les taux d'efficacité d'élimination de 85 à $92 \%$ pour la DBO5, DCO et MES, qui est conforme à la littérature sauf pour NTK qui est d'environ $77 \%$. Cependant, le système ne parvient pas à une cible, l'efficacité d'élimination acceptable lorsque le THS diminue à 6 et 3 heures, l'efficacité étant dans la plage de 57 à $72 \%$ pour le hr HRT 6 et dans la plage de 34 à $66 \%$ pour le HRT de 3 heures. Ceci indique que le procédé d'aération prolongée ne peut pas résister à de fortes variations de charges organiques ou de débit entrant. Pour le système IFAS utilisée dans cette étude, de bien meilleurs rendements d'élimination sont atteints . Pour HRT 18 heures, le taux d'élimination est de 92\% pour la DBO, DCO et MES et $80 \%$ pour ATK, qui est un niveau de performance plus élevé par rapport au processus d'aération prolongée. En outre, pour l' hormonothérapie substitutive de 6 heures, le taux varie de 90 à $92 \%$ de la DBO, DCO et MES et 80\% aussi bien pour TKN et, de même, pour le HRT de 3 heures, sauf que l'élimination de TKN diminue à environ $75 \%$. Malgré ces résultats prometteurs, des efforts supplémentaires devront être recommandés pour identifier les critères de conception fiables et profondes pour la technologie IFAS comme c'est le cas avec les systèmes existants de boues classiques et étendus activés .

MOTS CLÉS: boues activées ( AS ) - Modélisation informatique - Eaux usées domestiques - Ratio aération prolongée - F / M - GPS $\mathrm{X}$ - HRT - IFAS - Mise à niveau.

* $\quad$ Received: 16/9/2013, Accepted: 15/10/2013, Ref. No. 164, (Original paper)

+ Contact author (omonayeri@yahoo.com) 


\section{ASSESSING THE PERFORMANCE OF IFAS SYSTEMS \\ TO RAISE THE CAPACITY OF EXISTING WWTP \\ Ola D.S. EL monayeri , Abul- abbas E.Galal}

\section{INTRODUCTION}

A main lead for the Integrated Fixed-film Activated Sludge (IFAS) technology is providing additional biomass in wastewater treatment facilities in order to meet better effluent treated wastewater quality. This is done mainly to evade the need of adding extra tanks especially in cases of land deficiency or lack in financial resources as in most developing countries such as Egypt. Unfortunately, to A MLSS to about $3000 \mathrm{mg} / \mathrm{l}$ and "off-load" the solids loading in the clarifiers; in addition, the system could increase the sludge retention time which would then lead to better nitrification especially in cold climates (Brentwood, 2009). Moreover, the industry indicated that the IFAS system could provide a stable environment for the growth of the bacteria, thus achieve preferable Food / Micro-organism ratios and reduce the amount of sludge produced as reported by owners and engineers.

Back in 2003, the City \& County of Broomfield wastewater treatment plant (a $2^{\text {ndry }}$ treatment processes) was upgraded to a new biological nutrient removal process described as Integrated Fixed Film Activated Sludge (IFAS) using a moving bed plastic carrier element to help grow the biomass. The upgraded IFAS system included anaerobic and anoxic reactors to help meet new effluent TN and TP limits. The performance of the entire system since July 2003 averaged effluent concentrations of 2.4 $\mathrm{mg} / \mathrm{L}$ for BOD, $4.2 \mathrm{mg} / \mathrm{L}$ for TSS, $0.3 \mathrm{mg} / \mathrm{L}$ for NH3-N, $8.3 \mathrm{mg} / \mathrm{L}$ for NOx-N and $1.25 \mathrm{mg} / \mathrm{L}$ for TP while operating during this period of time the aerobic suspended MLSS SRT averaged 4 days, the MLSS concentration averaged 1,718 $\mathrm{mg} / \mathrm{L}$ and the SVI averaged $120 \mathrm{~mL} / \mathrm{L}$. The plant has operated with one set point for both the RAS and WAS rates for months at a time while meeting these very consistent effluent results (Rutt, et.al, 2006). Moreover, Hendy (2013) in his work used IFAS system in which the wastewater temperature varied from 21 to $32{ }^{\circ} \mathrm{C}$. According to his results, he concluded that a HRT range of 2-12 $\mathrm{hr}$, SRT range of 2-10 days, ammonia-N loading rate $\leq 0.13 \mathrm{~kg} / \mathrm{m}^{3} . \mathrm{d}$ could be leading design criteria for the IFAS system.

Egypt had 372 municipal wastewater treatment plants in 2012, treating an average of 10.1 million cubic meters per day (Global Water Intelligence, 2012). The capacity of Egypt's wastewater treatment plants was more than 11 million cubic meters per day, serving more than 18 million people. The number has increased 10 times between 1985 and 2005 (NWRC, 2007). The amount of water which is released into the Nile is 3.8 billion $\mathrm{m}^{3}$ per year, out of which only $35 \%$ was treated properly as of 2004 (IWRMP, 2005). Consequently, many of the existing wastewater treatment plants in Egypt are presently receiving higher flowrates with high organic loading rates; this in return has affected the final effluent quality of the treated wastewater, the mechanical equipment installed and concrete structure of the tanks.

\section{OBJECTIVES}

The prime objective of this research is to determine the ability of an IFAS system to enhance the removal efficiency in existing wastewater treatment plants with activated sludge process in developing countries. This has been done via two phases; the first phase includes experimental work in which three flowrates were examined once for a reactor without media and another while installing a biofilm media within the reactor and organic loads were measured for each case in the laboratory. The second phase included the use of computer simulation, namely GPS-X (Hydromantis, 2012) to validate the experimental work and evaluate the possibility of increasing the percentage removal of organic loads despite the increase in influent flowrates and organic loads compared to the actual design criteria of the plants. Simulation software developed according to IWA ASM models and integrating sophisticated biofilm modules for IFAS configuration are now widely recognized and used as powerful and accurate modeling tools (Brentwood, 2009). In order to support the experminents done using the IFAS system, a mathematical model including essential basic activated sludge processes and empirical equations was established (Sen, 1995; .Sen and Randall, 1996).

\section{SITE DESCRIPTION \& WORK PLAN}

The pilot used in this research was constructed in Zenein wastewater treatment plant located at 
Giza Governorate. It consisted of two tanks, a bioreactor and a final sedimentation tank, representing an extended aeration activated sludge system as illustrated in Figure 1.

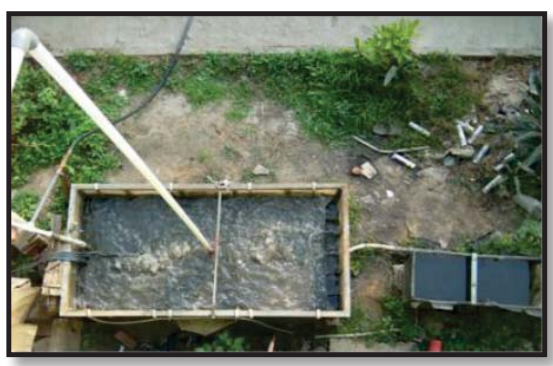

Figure 1: Components of the pilot plant located at Zenein WWTP

The Pilot plant consisted of an inlet UPVC pipe, $25 \mathrm{~mm}$ in diameter to discharge the flow to the pilot extended aeration tank, an overflow gravity pipe of the same diameter to discharged the excess flow to the open area nearby, an extended aeration tank using diffused aeration system with dimensions, 2.om long by $1.0 \mathrm{~m}$ width and with a depth of $0.4 \mathrm{~m}$ and a final clarifier which was $1.0 \mathrm{~m}$ long by $0.4 \mathrm{~m}$ width and water depth of $0.32 \mathrm{~m}$. The final clarifier had an outlet chamber as shown in Figure 1. The settled sludge in the clarifier was withdrawn by a pump with a total head of $3.0 \mathrm{~m}$ and maximum discharge $1000 \mathrm{l} / \mathrm{hr}$. The pipe was $125 \mathrm{~mm}$ in diameter made of UPVC and pumped the sludge from the final clarifier to the extended aeration tank.

As for the IFAS System used, a fixed media consisting of a set of sheets were installed on frames in a fixed location in the reactor. The sheets of media were looped around the top and bottom of the supporting bars, which were installed in the steel frames. The frames were supported from above by structural members attached to the tank walls, (Figures $2 \& 3$ ) and had the following dimensions:

- frame : 0.5 meter long by 0.42 meter wide at depth $0.25 \mathrm{~m}$

- sheet : 0.5 meter long by 0.5 millimeter wide at depth $0.25 \mathrm{~m}$
- frame contained eight sheets, spacing between two sheets was $6 \mathrm{~cm}$

- Total area of all sheets was $12 \mathrm{~m}^{2}$.

- The top of the frame was approximately 5 $\mathrm{cm}$ below the water surface.

- The bottom of the frames was about $10 \mathrm{~cm}$ above the bottom of the tank, to provide clearance for the air pipes located below.

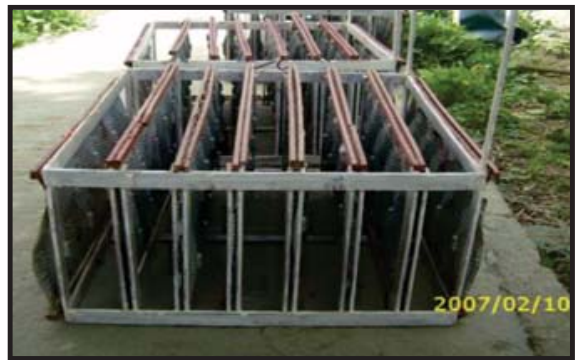

Figure 2: The installed framed media sheets

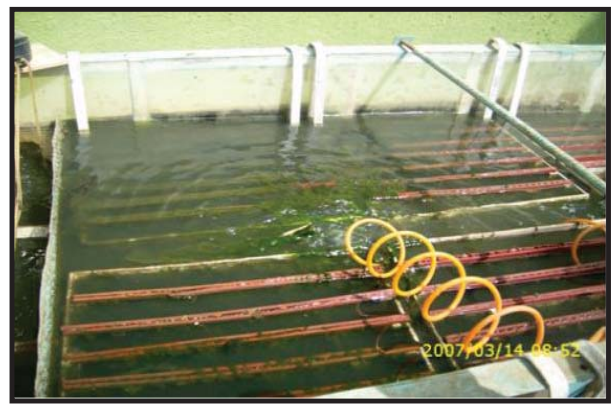

Figure 3: Media installed inside AT Model

Samples were collected and analyzed to determine the typical extended aeration to the IFAS efficiency. Samples were collected at the inlet extended aeration tank and outlets final sedimentation tank. The parameters measured in the lab included: $\mathrm{pH}$, temperature, $\mathrm{DO}, \mathrm{NH}_{4}, \mathrm{NO}_{2}$, $\mathrm{NO}_{3}, \mathrm{TKN}, \mathrm{COD}, \mathrm{BOD}_{5}, \mathrm{TSS}, \mathrm{VSS}, \mathrm{MLSS}$ and MLVSS.

Simulation software have been developed according to IWA ASM models with dependable biofilm modules for IFAS configuration and are now broadly recognized and used as influential and accurate wastewater treatment process modeling tools. 
Table 1: Operating conditions for the Experimental Work done Extended Aeration and IFAS system used:

\begin{tabular}{|c|c|c|c|c|c|c|}
\hline Item & \multicolumn{3}{|c|}{ Extended Aeration System } & \multicolumn{3}{|c|}{ Integrated Fixed Bioreactor System } \\
\hline Flowrate $\left(\mathrm{m}^{3} / \mathrm{d}\right)$ & 1.013 & 3.04 & 6.08 & 1.013 & 3.04 & 6.08 \\
\hline HRT (hr) & 18 & 6 & 3 & 18 & 6 & 3 \\
\hline Influent COD (mg/l) & 601 & 572 & 555 & 636 & 597 & 618 \\
\hline Influent $\mathrm{BOD}_{5}(\mathrm{mg} / \mathrm{l})$ & 273 & 279 & 291 & 300 & 312 & 309 \\
\hline Influent TSS (mg/l) & 316 & 317 & 311 & 320 & 318 & 317 \\
\hline $\begin{array}{l}\text { Yield Factor: } Y_{H}(\mathrm{gVSS} / \mathrm{g} \\
\text { COD) }\end{array}$ & 0.62 & 0.58 & 0.56 & 0.6 & 0.57 & 0.57 \\
\hline$Y_{\text {observed }}($ gVSS/g COD $)$ & 0.31 & 0.49 & 0.55 & 0.24 & 0.46 & 0.51 \\
\hline MLSS & 1380 & 1066 & 904 & 1970 & 1755 & 1894 \\
\hline$P_{X}(\mathrm{~kg} / \mathrm{d})$ & 0.139 & 0.661 & 1.43 & - & - & - \\
\hline Qexcess $\left(\mathrm{m}^{3} / \mathrm{d}\right)$ & 0.023 & 0.15 & 0.34 & 0.019 & 0.117 & 0.25 \\
\hline SVI & 151 & 195 & 205 & 145 & 150 & 150 \\
\hline $\operatorname{AOR}\left(\mathrm{m}^{3} / \mathrm{hr}\right)$ & 0.59 & 1.36 & 2.67 & 0.72 & 1.51 & 2.73 \\
\hline Total area of sheets $\left(\mathrm{m}^{2}\right)$ & - & - & - & 12 & 12 & 12 \\
\hline Biofilm rate $\left(\mathrm{kg} / \mathrm{m}^{3}\right)$ & - & - & - & $\begin{array}{l}0.25 \text { (TSS) } \\
0.18 \text { (VSS) }\end{array}$ & $\begin{array}{l}0.27 \text { (TSS) } \\
0.22 \text { (VSS) }\end{array}$ & $\begin{array}{c}0.4 \text { (TSS) } \\
0.32 \text { (VSS) }\end{array}$ \\
\hline
\end{tabular}

After intensive calibration, studies have been conducted specifically for a given IFAS media system; these models could be used with great reliability as preferred methods for designing IFAS systems for various wastewater treatment applications (Brentwood, 2009). Pilot studies with the actual media at the treatment facility are often used to develop site-specific design criteria and calibrate the model for an optimized process design with the highest confidence.

As for the modeling part which has been implemented using GPS_X (Hydromantis, 2012), the boundary operating conditions set for the experimental work and the results measured in the laboratory have been utilized for model validation, and assuring the positive impact of using IFAS systems in upgrading existing wastewater treatment plants. The results derived from both the field work and the modeling simulation shall be displayed in the coming section.

\section{RESULTS \& DISCUSSION}

As mentioned above, laboratory tests have been conducted at Zenien wwtp to test the effect of using IFAS system in enhancing the effluent treated quality and upgrading existing wastewater treatment plants receiving higher flowrates and / or organic loads compared to actual design criteria. Field tests have been applied for 3 different flowrate with different HRTs and model validation has been done using GPS_X. The following sections will display those results.

\subsection{Using the Typical Extended Aeration System with Different Q \& HRTs}

According to EPA (1997), extended aeration is considered to be a low rate activated sludge process which operates at low organic loading rates and $\mathrm{F} / \mathrm{M}$ ratios and with long hydraulic retention times and sludge ages. Consequently, little food is available in the system to support the micro-organisms present.

(i) Results obtained for Q1 $=1.013 \mathrm{~m}^{3} / \mathrm{hr}$ and
$\mathrm{HRT}=18 \mathrm{hr}$

The results obtained from the experimental tests showed that for the $1.013 \mathrm{~m}^{3} / \mathrm{hr}$ flowrate, the percentage removal achieved was $85 \%$ for $\mathrm{BOD}_{5}$, $89 \%$ for TSS, $88 \%$ for COD and $77 \%$ for TKN. The results obtained from computer simulation showed that the percentage removal computed was $93 \%$ for $\mathrm{BOD}_{5}, 88 \%$ for TSS, $88 \%$ for COD and $78 \%$ for TKN. The concentration of MLSS measured in the lab was $1380 \mathrm{mg} / \mathrm{l}$ compared to $1650 \mathrm{mg} / \mathrm{l}$ from the model. Thus the experimental values strongly validate those values obtained from simulation; hence further investigations could be done as shown in the coming lines. Figure 4 illustrates the concentrations of the parameters measured in the lab and those generated via simulation. 


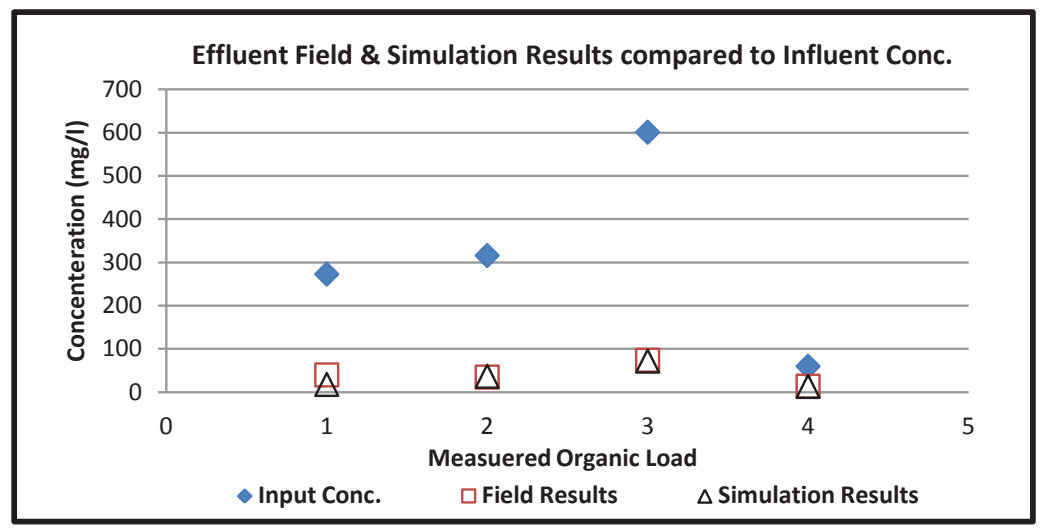

Figure 4: Comparison of measured parameters in the lab and those generated via simulation for the $1.013 \mathrm{~m}^{3} / \mathrm{d}$ flowrate for extended aeration

\section{(ii) Results obtained for $\mathrm{Q} 2=3.04 \mathrm{~m}^{3} / \mathrm{d}$ and HRT $=6 \mathrm{hr}$}

The results obtained from the experimental tests showed that for the $2.1 \mathrm{~m}^{3} / \mathrm{hr}$ flowrate, the percentage removal achieved was $60 \%$ for $\mathrm{BOD}_{5}, 72 \%$ for TSS, $59 \%$ for COD and $57 \%$ for TKN. The results obtained from computer simulation showed that the percentage removal computed was $64 \%$ for $\mathrm{BOD}_{5}, 50 \%$ for TSS, 57 $\%$ for COD and $68 \%$ for TKN. The concentration of MLSS measured in the lab was $1066 \mathrm{mg} / \mathrm{l} \mathrm{compared} \mathrm{to} 1230 \mathrm{mg} / \mathrm{l}$ from the model. Values obtained from the lab and simulation show that the percentage removal ratio has declined. This is expected since the retention time used is much less than that typical range for extended aeration systems as mentioned in the literature $(18-36 \mathrm{hr})$ with a removal ratio of $90-98 \%$ for $\mathrm{BOD}_{5}$ (Punmia,
1998). However still it is noticed the compliance of the lab results to those obtained from modeling except for that gap for TSS. This could be reasoned to some error in lab measurement. Figure 5 illustrates the concentrations of the parameters measured in the lab and those generated via simulation for the $3.04 \mathrm{~m}^{3} / \mathrm{hr}$ flowrate.

\section{(iii) Results obtained for $\mathrm{Q3}=6.08 \mathrm{~m}^{3} / \mathrm{hr}$ and HRT $=\mathbf{3} \mathrm{hr}$}

Similar to the previous flowrate, the results obtained from the experimental tests showed that for the $4.2 \mathrm{~m}^{3} / \mathrm{hr}$ flowrate, the percentage removal achieved was $52 \%$ for $\mathrm{BOD}_{5}, 66 \%$ for TSS, $53 \%$ for COD and $34 \%$ for TKN.

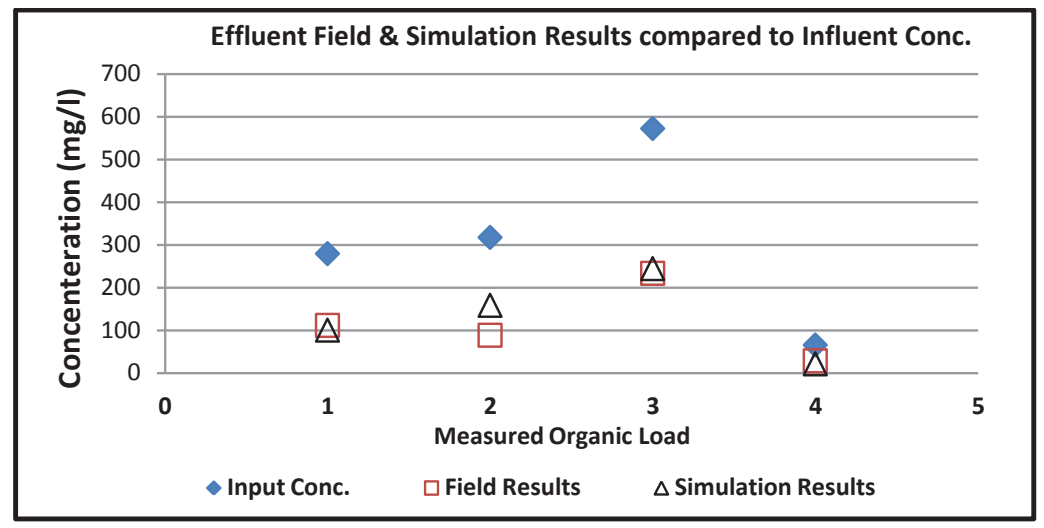

Figure 5: Concentrations of parameters measured in the lab and those generated via simulation for the $3.04 \mathrm{~m}^{3} / \mathrm{d}$ flowrate 


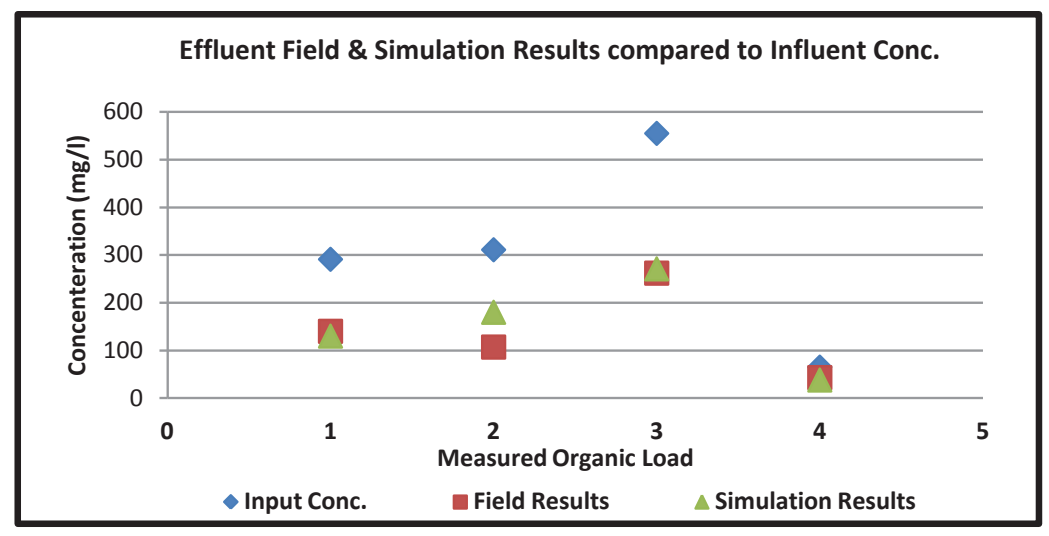

Figure 6: Concentrations of parameters measured in the lab and those generated via simulation for the $6.08 \mathrm{~m}^{3} / \mathrm{d}$ flowrate

The results obtained from computer simulation showed that the percentage removal computed was $55 \%$ for $\mathrm{BOD}_{5}, 42 \%$ for TSS, 51 $\%$ for COD and $42 \%$ for TKN. The concentration of MLSS measured in the lab was $904 \mathrm{mg} / 1$ compared to $1050 \mathrm{mg} / \mathrm{l}$ from the model. Values obtained from the lab and simulation show that the percentage removal ratio has declined. This is expected since the retention time used is much less than that typical range for extended aeration systems as mentioned in the literature $(18-36 \mathrm{hr})$ (Metcalf \& Eddy, 2005). However still it is noticed the compliance of the lab results to those obtained from modeling except for that gap for TSS. This could be reasoned to some experimental error. Figure 6 displays the concentrations of the parameters measured in the lab and those generated via simulation for the $6.08 \mathrm{~m}^{3} / \mathrm{hr}$ flowrate.

\subsection{Using Integrated Fixed Activated Sludge System (IFAS) with different Q \& HRTs}

According to their research, Sabzali, et.al (2011) stated that IFAS systems supplement the benefits of Fixed Film systems installed in suspended growth AS process. Fixed Film processes are characterized by their stability and ability to resist variations in hydraulic loads (shock loads). Moreover, not only could IFAS and MBBR systems enhance removal of organic nutrients, but they have proven to be reliable in treatment without encountering some of the troubles that may appear in typical suspended growth systems (Odegaard et al. , 1994, and Kermani, et al., 2008). The coming section represents the results obtained from the experimental and simulation work.

\section{(i) Results obtained for Q1 $=1.013 \mathrm{~m}^{3} / \mathrm{d}$ and HRT $=18 \mathrm{hr}$}

The results obtained from the experimental tests for this flowrate showed that the percentage removal achieved for $\mathrm{BOD}_{5}$ was $92 \%$, for TSS, 92 $\%$, for COD, $92 \%$ and $80 \%$ for TKN. The results obtained from computer simulation showed $92 \%$ for $\mathrm{BOD}_{5}, 93 \%$ for TSS, $92 \%$ for COD and $73 \%$ for TKN percentage removals. The concentration of MLSS measured in the lab was $1970 \mathrm{mg} / \mathrm{l}$ compared to $1040 \mathrm{mg} / \mathrm{l}$ from the model. Thus the experimental values strongly validate those values obtained from simulating the IFAS system indicating the strong reliability of using computer models such as GPS_X, BioWin, West, and Aquifas as long as model calibration to site conditions are achieved (Steichen \& Phillips, 2010) to design and/or check on operating conditions for such systems. Concerning the percentage removal, the results from both laboratory and simulation show the higher performance of IFAS system compared to the extended aeration system (typical AS system) and which comply with the findings of Sabzali, et.al (2011) who achieved $94.55 \%$ removal for COD using IFAS process and $81.62 \%$ using AS process for HRT of $16.1 \mathrm{hr}$. Figure 7 illustrates the concentrations of the parameters measured in the lab compared to those generated via simulation. Figure 8 shows the growth of biomass on the media used in this research. 


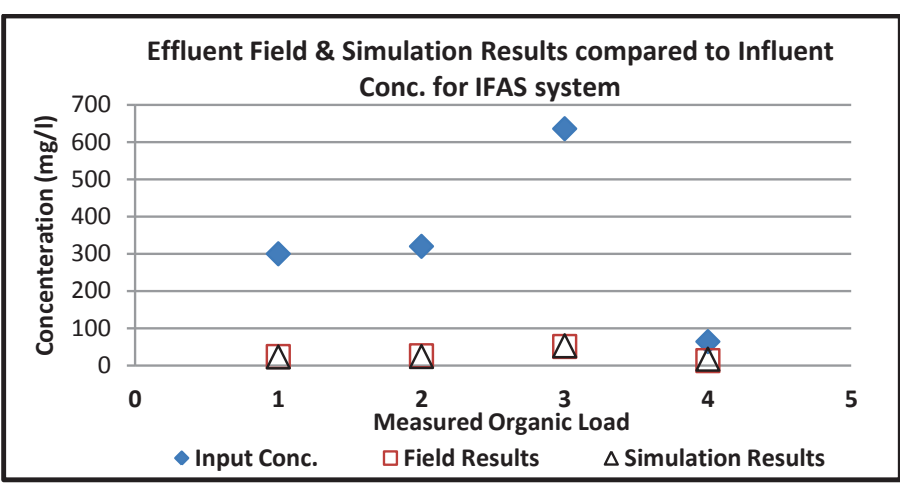

Figure 7: Concentrations of parameters measured in the lab and those generated via simulation for the $1.013 \mathrm{~m}^{3} / \mathrm{d}$ flowrate

\section{(ii) Results obtained for Q2 $=3.04 \mathrm{~m}^{3} / \mathrm{d}$}

\section{and HRT $=6 \mathrm{hr}$}

Since the first run using the IFAS system showed promising results, there was an encouragement to apply a second run with a higher flowrate, $3.04 \mathrm{~m}^{3} / \mathrm{d}$ and a shorter retention time, 6 hrs. Results obtained showed that the percentage removal attained was $92 \%$ for $\mathrm{BOD}_{5}, 92 \%$ for TSS, $91 \%$ for COD and $79 \%$ for TKN. The results obtained from computer simulation were $91 \%$ for $\mathrm{BOD}_{5}, 91$ $\%$ for TSS, $90 \%$ for COD and $80 \%$ for TKN. The concentration of MLSS measured was $1755 \mathrm{mg} / \mathrm{l}$ compared to $1650 \mathrm{mg} / \mathrm{l}$ from modeling. Again, the results indicate higher performance of the IFAS system which appears to be more stable and could handle higher flowartes compared to the AS system. This also comes in agreement with the findings of Sriwiriyarat et al. (1999) who used HRTs of

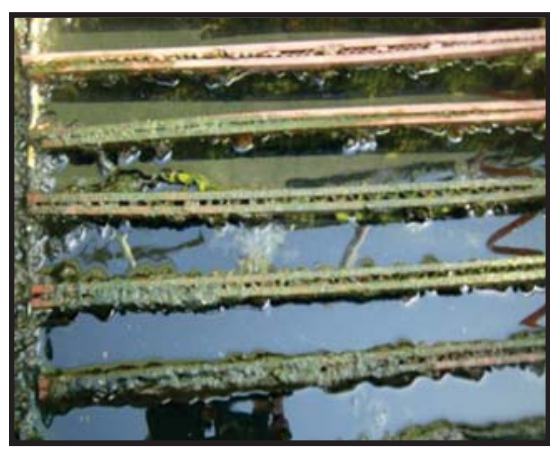

Figure 8: Growth of biomass on the media used for the IFAS system
6,8, and 10 hours using IFAS system and compared to AS method. Figure 9 illustrates presents the concentrations of the parameters measured in the lab before and after treatment compared to those generated via simulation.

\section{(iii) Results obtained for $Q 3=6.08 \mathrm{~m}^{3} / \mathrm{d}$ and HRT $=3 \mathrm{hr}$}

With the favorable results obtained from the previous two runs, a third run was implemented with a higher by doubling the previous flowrate to reach $6.08 \mathrm{~m}^{3} / \mathrm{d}$ with a shorter retention time of 3 hrs. Results obtained showed that the percentage removal ratios very similar to previous run and the results are illustrated in Figure $\mathbf{1 0}$ except for

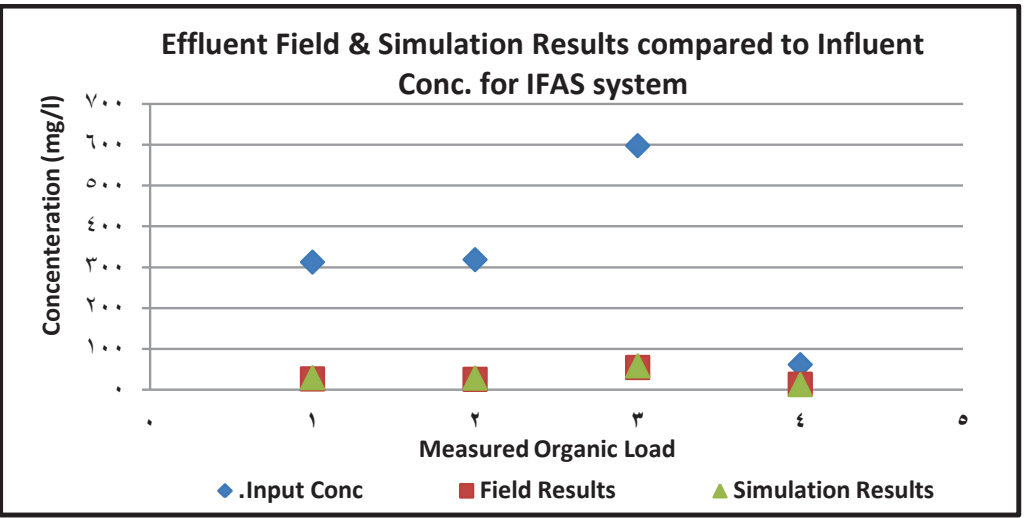

Figure 9: Concentrations of parameters measured in the lab and those generated via simulation for the $3.04 \mathrm{~m}^{3} / \mathrm{d}$ flowrate. 
TKN where the percentage removal decreased to $76 \%$ as measured in the lab and to $74 \%$ as simulated. The concentration of MLSS measured was $1894 \mathrm{mg} / \mathrm{l}$ compared to 2260 $\mathrm{mg} / \mathrm{l}$ from modeling. In his research, Sabzali, et.al (2011) decreased the retention time in his system to $3.8 \mathrm{hr}$ and increased the concentration of COD from 326.8 to 446.3 $\mathrm{mg} / \mathrm{l}$; consequently, the removal of $\mathrm{CO}$ decreased from $94 \%$ to $86 \%$. Thus results may direct to the promising results of IFAS system with a minimum detention time of 4 $\mathrm{hr}$ depending on influent organic loads and boundary operating conditions. Figure 11 presents an overall comparison for the measured done and removal ratios attained for the three tested flowrate for the IFAS and extended aeration (AS) processes used.
Figures 9 to $\mathbf{1 2}$ illustrate a further comparison for the values of the parameters measured: $\mathrm{BOD}_{5}$, TSS, COD, and TKN for the three flowartes used in this research with their corresponding HRTs. As presented below, there is a unique validation for the computer model used (GPS_X) with the experimental measurements done at Zenien WWTP.

Moreover, the tested flowrate for the extend aeration system show that as the flowrate increased, the HRT decreased and consequently the final effluent concentration of each of the four parameters increased.

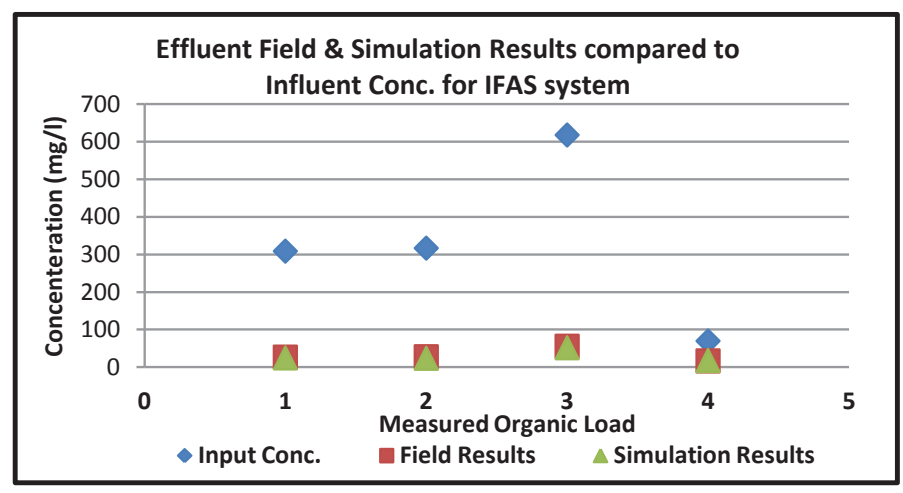

Figure 10: Concentrations of parameters measured in the lab and those generated via simulation for the $3.04 \mathrm{~m}^{3} / \mathrm{d}$ flowrate

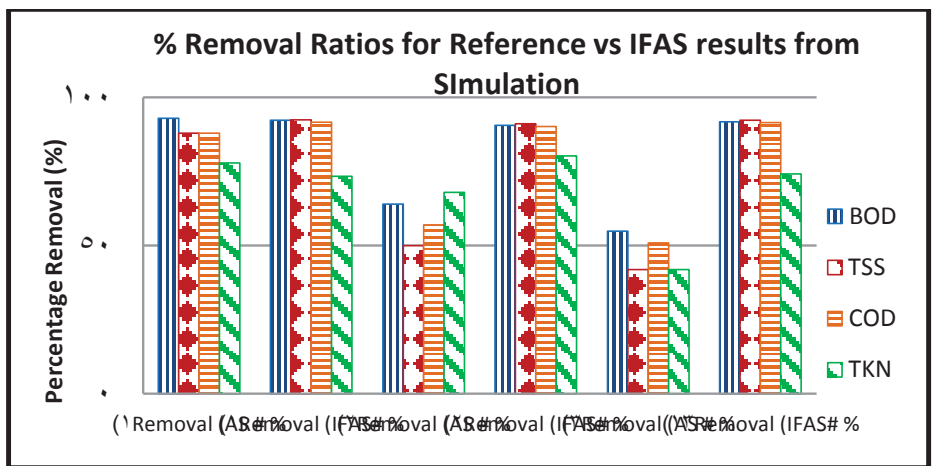

Figure 11: Comparison for the \% removal ratio for the measured parameters for the three testedflowarate: Q1, Q2, and Q3. 


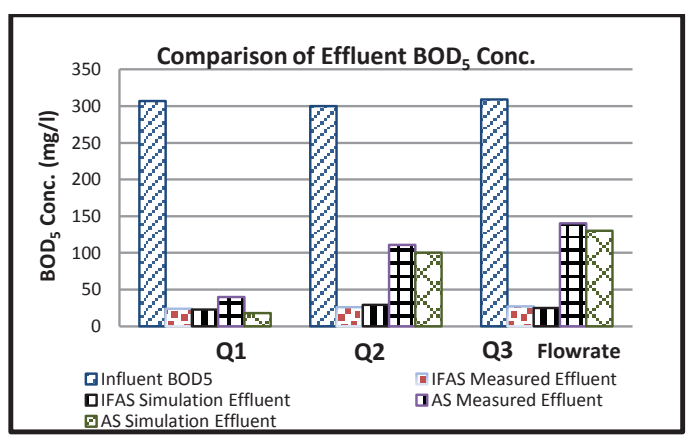

Figure 10: Validation of measured $\mathrm{BOD}_{5}$ from Lab and simulation for IFAS \& AS systems

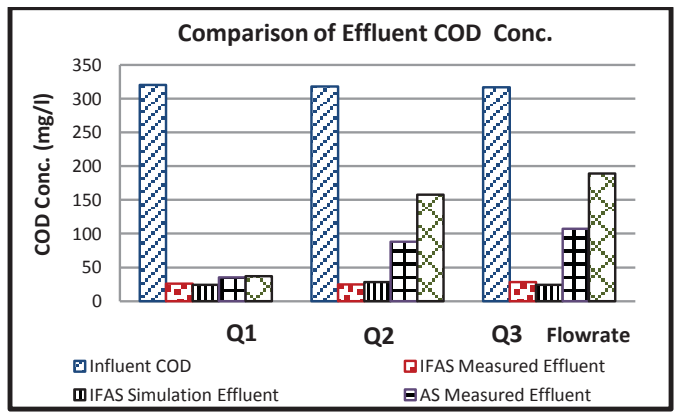

Figure 12: Validation of measured COD from Lab and simulation for IFAS \& AS systems

Aspreviously mentioned, this complies with the literature and with results of other researchers. On the other hand, for the IFAS system, as the flowrate increased while the HRT decreased, the final effluent quality of the treated wastewater was not affected. The percentage removal ratio was maintained high except for TKN for the third run whose removal ratio decreased to $76 \%$. Thus, the integrated fixed film activated sludge process continues to retrofit the activated sludge process in which a high volumetric density of microorganisms amass via natural attachment as biofilm onto the media placed in the aeration tank and thus making the IFAS system capable of being stable and flexibly towards fluctuation in influent flowrate and organic load (Sriwiriyarat, 1999).

\section{CONCLUSIONS}

By accomplishing the experimental work and validating the results using computer modeling, the following conclusions could be summed up as follows:

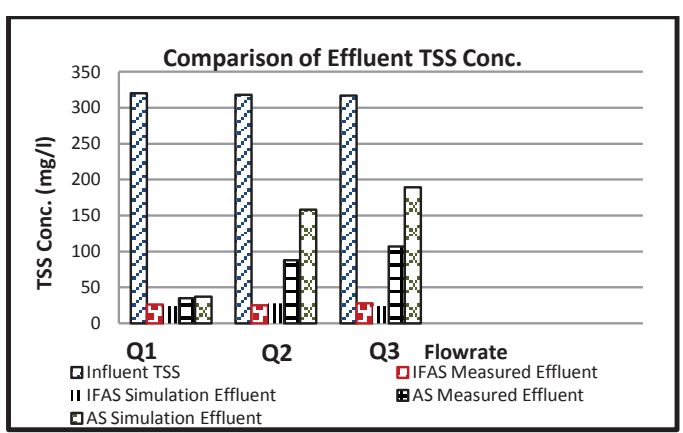

Figure 11: Validation of measured TSS from Lab and simulation for IFAS \& AS systems

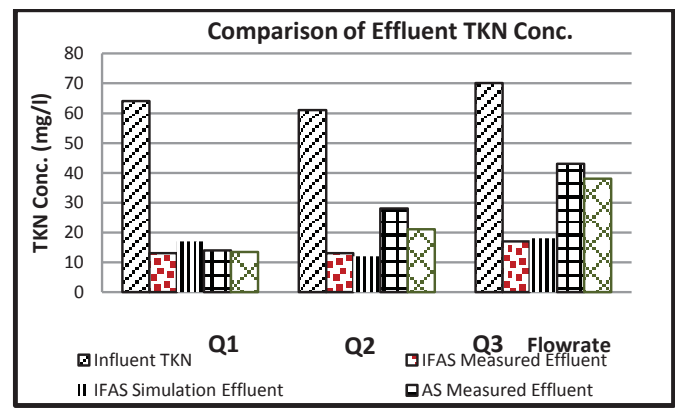

Figure 13: Validation of measured TKN from Lab and simulation for IFAS \& AS systems

(i) The extended aeration system (AS) performed well with a HRT of 18 hours where the removal efficiency ranged from 85 - $92 \%$ for BOD, COD, and TSS which complies with the literature except for TKN which was about $77 \%$. This might be due to minor deficiency in the amount of air provided during the field process.

(ii) However this system failed to target the acceptable removal efficiency when the HRT decreased to 6 and 3 hours where it reached a range of 57 to $72 \%$ for the $6 \mathrm{hr}$ HRT and ranged from 34 to $66 \%$ for the 3 hour HRT. This gives a strong suggestion that the extended aeration process couldn't resist high variations in organic loads or incoming flowrate.

(iii) For the IFAS system used in this study, much better removal efficiencies have been achieved. For HRT $18 \mathrm{hr}$, the removal ratio was $92 \%$ for BOD, COD and TSS and was $80 \%$ for TKN, thus a higher level of performance compared to the extended aeration process. 
(iv) Furthermore for the 6 hour HRT, the ratio ranged from 90 to $92 \%$ for BOD, COD, and TSS and $80 \%$ as well for TKN and similarly for the 3 hour HRT except that the removal of TKN decreased to about $75 \%$.

(v) This may draw the attention towards the better performance of IFAS system and its ability and flexibility towards handling shock loads and even at lower HRT. In his work, Din (2013) mentioned that systems with biofilm could have a HRT range from 1 -4 hours considering a minimum DO range of $2.5-3 \mathrm{mg} / \mathrm{l}$ for BOD removal and that would increase to $3.5-6 \mathrm{mg} / \mathrm{l}$ for nitrogen removal.

In conclusion, the IFAS has shown to be a promising tool to be used in upgrading and / or expansion of existing wastewater treatment plants.

\section{REFERENCES}

1. Abdel-Gawad, S. Actualizing the Right to Water: An Egyptian Perspective for an Action Plan Ministry of Water Resources and Irrigation, National Water Research Center (2007). Retrieved on 2012-04-30.

2. Boltz, J.P. "Overcoming Hydraulic Limitations of the Integrated Fixed Film Activated Sludge and Moving Bed Biofilm Reactor Process." Florida Water Resources Journal, January 2012, Wastewater Treatment.

3. Brentwood Industries, Inc. www.brentwoodprocess.com/ifas main.ht $\underline{\mathrm{ml}}-2009$

4. Din,A. "Innovative Applications of MBBR/IFAS Upgrades, Retrofits, and New Builds Around the World.: Headworks BIO Inc. February 19, 2013.

5. Federation of Canadian Municipalities and National Research Council . "Solids Inventory Control for Wastewater Treatment Plant Optimization. " Issue No. 1.0 . ISBN 1-897094-60-4. Publication Date: March 2004.
6. Global Water Intelligence. "Wastewater focus moves out of the city". November, 2012.

7. Hendy, I.A., El Monayeri, D., Al Mokadem, S., and Nagieb, A. "Modeling of BiofilmASP." A Thesis submitted to the Faculty of Zagazig University, Faculty of Engineering in partial fulfillment of the requirements for the degree of Doctor of Philosophy in Environmental Engineering, 2013.

8. Hydromantis inc., GPS-X User's Guide. Version 6.2, Canada, 2012.

9. Integrated Water Resources Management Plan (IWRMP), The Ministry of Water Resources and Irrigation; Arab Republic of Egypt (2005), Retrieved on 2008-12-12.

10. Karia, G.L. and Christian, R.A. " Wastewater Treatment: Concepts and Design Approach." New Delhi - 110001. ISBN: 978-81-203-2860-0 Published by Asoke K. Ghosh, 2008.

11. Kermani, M. B. Bina, H. Movahedian, M.M. Amin, M. Nikaein,"Application of Moving Bed Biofilm Process for Biological Organics and Nutrients Removal from Municipal Wastewater," American Journal of Environmental Sciences, vol.4, no. 6, pp.675-682, 2008.

12.Metcalf \& Eddy, Inc. "Wastewater Engineering: Treatment, Disposal, and Reuse." 3rd Edition. McGraw-Hill, New York, P.1661. 2005.

13.Odegaard, H. , B. Rusten, T. Westrum,“ A new moving bed biofilm reactorapplications and results," water Sci. Technol.,vol. 29, pp.157-165, 1994.

14. Punmia, B.C. "Wastewater Engineering" Laxmi Publications LTD, New Delhi, ISBN: 81-7008-091-6, 1998.

15. Rutt, K., Seda1, J. and Johnson, C.H. AnoxKaldnes, Inc. "Two Year Case Study of Integrated Fixed Film Activated Sludge (IFAS)." Located at Broomfield, Co. WWTP. City \& County of Broomfield 2985 West 124th Street Broomfield, CO 80020. Copyright (C) 2006 Water 
Environment Foundation. All Rights Reserved pp. 225-239.

16. Sabzali, A., Nikaeen, M. and Bina, B. "Evaluation o Cigarette Filters Rods as A Biofilm Carrier in Integrated Fixed Film Activated Sludge Process." World Academy of Science, Engineering and Technology 51, 2011.

17. Sen, D. and Randall, C.W. "Mathematical model for a multi-CSTR integrated fixed film activated sludge (IFAS) system". Proc: Water Environment Federal, $69^{\text {th }}$ Annual Conference \& Exposition, Part III Municipal Wastewater Treatment, Dallas, TX, 1996.

18. Sen, D. "COD Removal, Nitrification and Denitrification kinetics and mathematical Modeling of an Integrated Fixed Film Activated Sludge (IFAS) System". Ph.D. Dissertation, Virginia Tech, Blacksburg, VA 24061, 1995.

19. Sriwiriyarat, T. "Computer Program Development for the Design of IFAS Wastewater Treatment Processes." Thesis submitted to the Faculty of Virginia Polytechnic Institute and State University in partial fulfillment of the requirements for the degree of Master of Science in Environmental Engineering. Blacksburg, Virginia, April 28, 1999.

20.Steichen, M. and Phillips, H.M. "Process and Practical Design Considerations for the IFAS and MBBR Technologies", IFAS and MBBR Webcast, Black \& Veatch, March, $18,2010$.

\section{Abbreviations:}

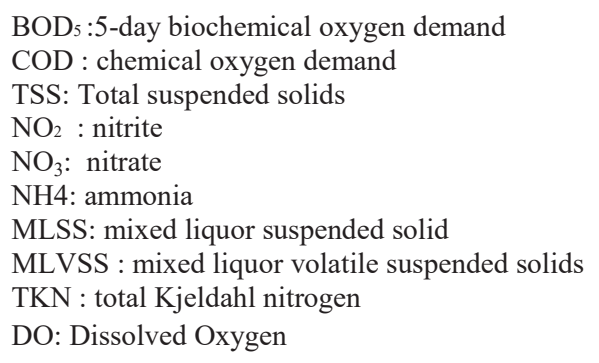

